\title{
On some Constituents of the Cell.
}

\author{
BY \\ JAMES ELLIS HUMPHREY, S.D., \\ Lecturer in Botany, Johns Hopkins University, Baltimore, U.S.A.
}

\section{With Plate XX.}

\begin{abstract}
A YEAR and a half ago the writer published ('94) a brief A preliminary account of the results of studies on the cell, carried on in the Botanical Institute at Bonn, under the inspiring guidance of Professor Strasburger. Since then these studies have been continued and extended in America, and meanwhile several papers bearing on the same questions have appeared. It seems, therefore, now worth while to examine the views then brought forward in the light of the latest and fullest evidence from all sources. Various details and general considerations which are stated in my earlier paper will hardly require to be repeated here.

The question as to the nature of the bodies long known as nucleoli has been made prominent by a paper of Zimmermann ('93) on their behaviour during karyokinesis. These bodies, while they readily take up very many stains, and are perhaps the most conspicuous features in preparations of the resting nucleus, are not so stained by all media as to be readily distinguishable from all other constituents of the cell. But until our knowledge of the higher organic compounds is

[Annals of Botany, Vol. IX. No. XXXVI. December, I895.]
\end{abstract}


greatly increased, the best staining methods will offer the only trustworthy means for their study. We know certain combinations which give to the nucleoli in all stages a sharply differential colour by which they can be unhesitatingly distinguished from all other bodies in the cell. They vary greatly, as is well known, in form, size, and position in the nucleus, and sometimes, as Zimmermann has shown, outside of it. But, so long as they are present in size recognizable by the highest powers, their reaction with certain stains remains characteristic. A favourite combination with many students for differentiating the chromatic and nucleolar elements of the nucleus has been the mixture of fuchsin and iodine green, first recommended by Babes and introduced into botanical technique by Strasburger. This combination was used by Zimmermann in his studies, with the addition of an after-treatment of the sections with alcohol containing iodine and acetic acid. This addition constitutes a real improvement in the process by increasing the sharpness of the preparations obtained, and the permanence of the stain. The nucleoli take, under this treatment, a blood-red colour, which is not approached by that of any other cell-constituent.

Zimmermann's argument is based on the occurrence of nucleolar masses outside of the nucleus during karyokinesis, a fact which no one will dispute. Several years before his observations, very large and numerous nucleolar masses had been observed by Strasburger in the cytoplasm of the wall layer of the embryo-sac of some Amaryllidaceae, and Zimmermann has done good service in showing that the phenomenon is more common than had previously been suspected. He has found the 'extranuclear nucleoli' to be sometimes abundant in the cytoplasm of cells from a large number of tissues, both during nuclear division and in the resting-state. But he attempts to show that the nucleoli are normally thrown out of the nucleus during division, remaining in the cytoplasm, entire or in fragments, and being taken up again by the daughter-nuclei resulting from the division. He regards the nucleoli as true organs of the nucleus derived 
directly from each other, and seeks to establish the principle, 'Omnis mucleolus e mucleolo,' as of equal value with the longaccepted statement of Flemming, 'Omnis nucleus e nucleo.' This is directly contrary to the generally prevailing view, that the nucleoli consist of a reserve substance which is ordinarily dissolved or otherwise changed during the earlier stages of karyokinesis, so that they are no longer recognizable as nucleoli.

The results of my earlier studies upon this question, begun soon after the appearance of Zimmermann's paper, have already ('94) been briefly stated. More recently Guignard ('94) and Strasburger ('95) have discussed the question. And a somewhat fuller account of its present status seems not to be superfluous, especially since Guignard seems to take a less definite position than is warranted by the facts he admits.

The fate of the nucleoli during karyokinesis has, very naturally, been discussed by almost every writer on that process, since those bodies are so conspicuous when present. And the number of observed cases of their persistence during the spindle-stages or of their occurrence in the cytoplasm had been so small before the publication of Zimmermann's results that they had been practically ignored. The fundamental significance attached to them by this author led to a renewed investigation of the facts. In my examination of spore- or pollen-mother-cells of Osmunda regalis and O. cinnamomea, Psilotum triquetrum, Ceratozamia longifolia, and Convallaria majalis, the first divisions in the spores of Pellia epiphylla, root-tips of Vicia Faba, Hyacinthus sp., and Allium Cepa, and the wall-layer from the embryo-sac of Leucojum aestivum, I have found only in rare cases a trace of nucleoli during the middle stages of karyokinesis, or of any in the cytoplasm at any stage. Reference to the figures accompanying my earlier paper and the present one will show what has been found to be the general condition of these bodies during the chief phases of nuclear division. Figs. 2 to 6 on the plate given herewith show several steps in the first division of the spore-mother-cell in Osmunda regalis, while Figs. II and $\mathbf{I} 2$ 
of my former paper ('94) and Fig. 7 of the present one show some stages in its second division which yields the sporecells. Not one of these shows any nucleolar substance in the cytoplasm; nor does any in which the nuclear membrane is not intact show it within the nuclear cavity. It is not necessary to go into a detailed discussion of the matter, for Zimmermann has stated his position so uncompromisingly that, as Strasburger has said ('95), a single case of the solution and subsequent reappearance of the nucleoli during division overturns it at once. If the nucleolus is a definite organ, derived only from its like, it must persist as such so long as the cell is active. Zimmermann himself admits that he has not been able to see it in all cells with dividing nuclei in the apex of the stem of Phaseolus. I have seen hundreds of karyokinetic figures in cells of both vegetative and reproductive tissues of all the plants above named, which showed no trace of any substance reacting to stains like the nucleoli. Besides, when nucleolar globules are found in the cytoplasm they are as likely to remain there as to be taken into the nuclei resulting from the division. There is not the least indication of any provision for their return to a daughternucleus after being thrown out from the mother. (Cf. Fig. 2 of my previous paper.)

Strasburger ('95) finds that, in agreement with his earlier statements, the nucleolus in the pollen-mother-cells of Lilium usually becomes entirely dissolved at the time of the formation of the spindle-fibres. And he adds that when a nucleolus is thrown out into the cytoplasm, this does not happen until it has been greatly reduced in volume, apparently by the solution of its substance. Guignard ('94) states, as a result of his study of Psilotum, that the persistence of the nucleoli is much rarer than their solution, and that the re-entrance of extranuclear nucleoli, when present, into the new nuclei is by no means a constant feature. In my examination of Psilotum, not a single well-marked case of extranuclear nucleoli was found. So far as the final divisions of the spore-mother-cells are concerned, Guignard found them almost equally rare; 
but in the divisions of the sporogenous cells to form the definitive spore-mother-cells, he found nucleolar substance much more abundant, and its occurrence in the cytoplasm correspondingly common. The material of Psilotum at my disposal, from the Botanic Garden at Bonn, showed only the spore-formation from the definitive mother-cells, which accounts for my having failed to agree in all respects with Guignard's observations. The fact that in Osmunda the definitive mother-cells are formed in autumn, has prevented the study of the divisions preceding their formation, my material having been collected in early spring. But if the extranuclear nucleoli are sometimes common in certain cells, this does not alter the fact that they are extremely rare in others, or lessen the force of the evidence against the view which regards the nucleolus as a permanent organ. Guignard does not seem to have sufficiently emphasized this point.

It is hardly necessary to repeat what was pointed out in my preliminary paper, that the great variability and evident passivity of the nucleoli are equally opposed to the conception of their definiteness and permanence. Their inconstant form, the readiness with which they break up or fuse together, and their tendency to assume the globular form when unhampered and not too large, all point unmistakably to the probability that they are of a fluid consistency, while their gradual disappearance in the early stages of division, as the karyokinetic forces come into full activity, and their equally gradual reappearance as this activity is ceasing, show plainly that they are directly acted upon by those forces. The constant occurrence of nucleoli in the nuclei of most widely different plants indicates the importance to the cell of the material which takes this form during its less active condition. Very careful studies of preparations from a large number of plants, stained with the best reagents for nucleolar substance, have quite failed to show me any change in the staining properties of the more permanent cell-constituents, which would give an indication of the distribution of the material of the dissolved nucleoli, although some writers have 
believed they have observed such a change. It is a common observation that a disappearing nucleolus within the nucleus often loses its staining power more rapidly than it decreases in size, though remaining distinctly stainable to the last. These facts seem to confirm the belief that the nucleoli are indefinite masses of a reserve substance, which, for want of chemical knowledge, we must call nucleolar substance, or, with Schwarz, pyrenin, and which undergoes a chemical change, in consequence whereof it loses its power to take up stains. They are, then, strictly comparable, to borrow my previous comparison, with the drops of oil in the Castor Bean, which disappear as oil-drops during the active life of the plant, to reappear in the resting-stage of the new seeds. There is no evidence that the nucleolar substance which appears in the daughter-nuclei after division is identically the same as that which disappeared just before the division. It can only be said to be a chemically similar substance. The fact that not all of the nucleolar material in a cell is always changed, may show nothing more than that more may sometimes be produced than can be changed at once. We know, as yet, so little about the part played by this substance and about the relation of nutrition and other conditions to its formation in the cell, that it is idle to speculate upon its significance.

The latest view of the rôle of the nucleoli ${ }^{1}$ is that of Strasburger ('95), who is led by his observations on Larix to believe that they furnish the material for the formation of the spindle-fibres. I can add nothing at present to the discussion of this question.

Zimmermann's demonstration of the not infrequent passage of nucleolar substance into the cytoplasm, and the pretty generally accepted fact that in many cases extranuclear substance contributes to the spindle-fibres, deserve emphasis as indicating a free interchange between all parts of the cell,

${ }^{1}$ More exact information concerning the nature of the nucleoli in animal cells, and whether any of the bodies included by zoologists under this name are chemically similar to the nucleoli of plants, is greatly to be cesired. 
and as supporting, in a measure, Boveri's view that the socalled nuclear sap is not a specific or peculiar substance. Evidence from the botanical side is much to be desired, as to whether, as this author believes, the nuclear membrane is merely a bounding layer of the cytoplasm enclosing the nuclear cavity.

Zimmermann ('93) observed in the sexual cells of Litium Martagon that, as he believes, only at a certain early stage of their division the nucleolus becomes flattened against the nuclear membrane, constituting what he has called its sicklestage, which was earlier referred to by Strasburger under the names 'Sekretkörperchen' and 'Paranucleolus.' $\mathrm{He}$ has attempted to connect this peculiar phenomenon with the reduction of the chromosomes, holding that it occurs only in the stage immediately preceding that process. During studies of various tissues, my attention was occasionally attracted by crescent-shaped accumulations against the nuclear membranes, often so great as to distort the nucleus. These are commonly present, if at all, in all the nuclei of a section, even when it includes both vegetative and reproductive tissues, and in resting nuclei as well as in those beginning to divide. The presence of these accumulations always on the side of the nucleus turned away from the nearest surface of the organ (cf. Figs. 3 and 4 of my previous paper) showed clearly that they are caused by the uneven penetration of the fixing fluid, which carries with it, until stopped by the nuclear membrane, certain deeply staining constituents of the nucleus. The reactions of the accumulations with stains made it very doubtful if they contain any nucleolar substance, but rather chromatin, a conclusion with which Strasburger has lately expressed ('95) his agreement. Since no similar bodies with the reactions of nucleoli were found in the tissues examined, it was believed that these represented the 'sickle-stage' of Zimmermann, which was therefore explained as due to imperfect fixation of the material. This identification was probably hasty, in view of the fact that Zimmermann figures his bodies as staining precisely like nucleoli. And he has 
since ('94) insisted upon the restriction of the 'sickle-stage' to a special phase of sexual cells. Strasburger ('95) has lately stated that the nucleolus may be flattened against the nuclear wall by the fixing fluid at an early stage of the prophase, when the nucleus is, as various observers have pointed out, peculiarly sensitive to reagents. Renewed examination of a large number of preparations has failed to show me any instance of this sort, but there is no reason for doubting that such displacement sometimes occurs, though far less commonly than the heaping up of chromatic substance.

If the so-called 'sickle-stage' bears any relation to the passage from sporophyte to gametophyte marked by the reduction in the number of chromosomes, as Zimmermann believes, it should be found always during the prophase of the first division of the definitive pollen- or spore-mother-cell. Yet, in the study of a very large number of such cells in the very stage indicated, and from several different plants, I have been able to find no such sickle-shaped nucleolus, nor indeed any nucleolus, in contact with the nuclear membrane. For the quick fixation of the nuclear constituents with the least possible displacement, the trial of many fluids has led me to prefer, in general, the alcoholic to the aqueous media. Of the latter, Hermann's fluid seems oftenest to do well. Merkel's fluid, recommended by Zimmermann, is much less satisfactory. But alcohol, sublimate-alcohol, or the fluid recommended for some animal tissues by Mann, are the most to be recommended for vascular plants, especially for reproductive tissues. As the formula for Mann's fluid has not, to my knowledge, been published in a botanical journal, it may be worth while to give it here:-

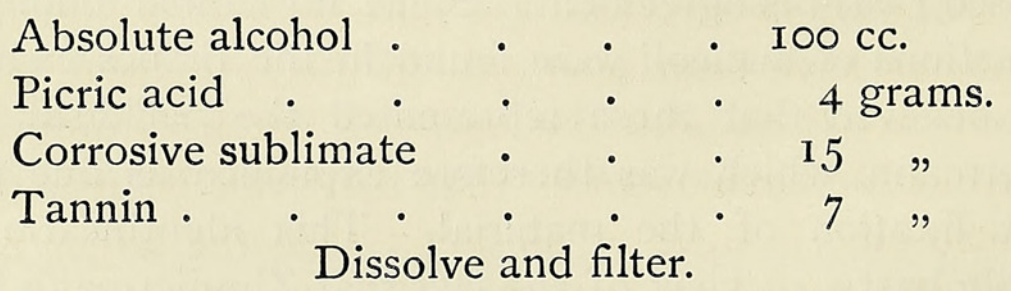

While it is, therefore, impossible to say positively what is 
the real nature of the 'sickle-stage,' it seems probable that it will prove to be a nucleolus, and not chromatic substance, as I formerly thought, but displaced and flattened by the unequal penetration of the fixing fluid, as before indicated. Strasburger appears to share this belief. The evidence we now have is quite too slight to justify the attachment of any importance to this particular form.

It is not yet nine years since the fundamental importance of the structures variously known as attraction-spheres, directivespheres, and centrospheres, was first suggested, almost simultaneously, by van Beneden and Neyt and by Boveri; and it is four years less since they were described for plant-cells by Guignard ('91). Since then they have been observed by several investigators in various vegetable tissues; but, on the other hand, it is certain that not all the structures which have been so regarded have really been centrospheres or centrosomes. The small size and comparative inconspicuousness of these bodies, which caused them to be so long overlooked in animal cells, are still more pronounced in case of plants, and make their study one of extreme difficulty. In the best and clearest vegetable preparations yet obtainable, their demonstration leaves very much to be wished for, in comparison with successful slides from animal tissue.

There are now generally recognized two more or less distinctly differentiated parts of these bodies, and the limitations of the names applied to them by Strasburger ('92), though not all first used by him, has been largely adopted by both botanical and zoological writers. A tiny central body, the centrosome, is usually distinguishable from the surrounding globular, hyaline mass, the astrosphere; these portions together constitute the whole structure, the centrosphere. In plants the centrospheres have been seen only in the cytoplasm, usually in intimate relations with the nucleus; but it is only under most favourable circumstances that they can be recognized. The centrosome is little or no larger than the larger microsomes of the cytoplasm, and can only be recognized when it is surrounded by an astrosphere of sufficient breadth to 
characterize it. That it sometimes exists without an astrosphere, as Boveri believes, still requires proof so far as plantcells are concerned; but this seems by no means impossible. At present we are practically restricted to the presence of the astrosphere as a diagnostic character. It is well known that the cytoplasmic microsomes are commonly surrounded by clear diffraction-areas, which are the wider as the microsome is larger. These areas, however, are never so wide as the well-developed astrosphere, and their optical properties are different. They appear as narrow and empty or watery rings about the microsomes; while the true astrosphere is more strongly refractive, appearing like a clear thick drop of jelly with a darker point, the centrosome, at its centre. The attempt is made to show these differences in Fig. 12, where both centrospheres and large microsomes are seen; but it is impossible to represent with the pencil the optical difference just described. The advantage of conspicuous cytoplasmic radiations guiding to the centrospheres, at least in certain stages, which are of great assistance in most animal cells, is quite wanting among plants with the exception of a few cases ; and, even in these, the radiations are far less pronounced than in animals.

Various stains have been said to possess a specific selective power for these bodies, or at least for the centrosomes. A careful trial of all the important methods proposed for staining them which have come to my notice, as well as of various unpublished treatments, has entirely failed to yield any satisfactory results. Stains which show a strong affinity for the cytoplasm often include these bodies in the diffuse colouring they impart; but I have not yet succeeded in differentiating them beyond a slight darkening of the centrosome in some cases. It would be superfluous to enumerate all the methods which have been tried, but it may be well to say that neither Heidenhain's iron-haematoxylin stain, Hermann's process with pyroligneous acid and haematoxylin, nor Rawitz's new method ('95) of inverse staining, has given better results than others. The first two of these stains bring out quite as 
sharply, or even more distinctly, the larger microsomes and various other proteid granules, such as leucoplasts, when present ; and the result is only confusion and uncertainty (cf. Fig. I2). Boveri ('95) states that the egg of the Sea-Urchin contains numerous granules which stain as deeply with ironhaematoxylin as the centrosomes. No treatment has yet enabled me to see these bodies more distinctly than after simple staining with the gentian-violet-eosin combination recommended by Farmer ('94), or according to the fuchsiniodine-green method used by Zimmermann. The substitution of acid fuchsin for fuchsin in the last mixture seems to offer no advantages.

Since the centrospheres are relatively so small, the chances of their concealment are correspondingly great. Thus, unless a section be taken in the right plane, they may be easily hidden beneath the nucleus, as probably in Fig. 2. Or, if a section be not very thin and the centrospheres in a given cell lie below the surface of the section, covered by a thin layer of the granular cytoplasm, they are very effectually concealed. These possibilities must be borne in mind in the consideration of any account of the presence or absence of centrospheres.

It may be remarked that these results of my experience in the study of these bodies coincide, in the main, with those of Guignard ('94). It is also of interest to observe that Boveri remarks, in his last admirable discussion ('95) of the centrosome question, upon the importance of 'the clear space and the radiations' for the recognition of the centrosome in many animal cells. One may be pardoned serious doubts whether all the appearances heretofore interpreted as centrospheres by zoologists really justify such interpretation.

Among the most clearly recognizable plant centrospheres yet seen are those figured for Sphacelaria by Strasburger ('92) and the writer ('94), and for Pellia by Farmer and Reeves ('94), and by Strasburger ('95). I have been able also to observe them in material of $P$. epiphylla collected near Baltimore. In both of these cases cytoplasmic radiations render considerable aid to the observer. The relation of the centro- 
spheres to nuclear division, and their apparent control over the formation of the spindle in determining the position of its poles, are too familiar to need description here. My own experience agrees with that of Farmer and of Strasburger in regard to the extreme difficulty of recognizing these organs at the poles of the spindle in Pellia, or in the resting cells. On the other hand, I have observed centrospheres in cells in nearly all conditions of rest and of division in a variety of plant-tissues, including most of those enumerated above in connexion with the investigation of the nucleoli. My observations on Psilotum have been confirmed and extended to every phase of cell-life by Guignard ('94), and Strasburger ('95) has added Larix europea to the list.

A favourable plant for the study of the structures in question is Osmunda regalis. Here they are not quite as large, as a rule, as in Psilotum, but in their occurrence and behaviour they quite agree with those of the latter plant. Sections of the sporangia of $O$. regalis, collected at the very beginning of growth in the spring, show the various stages in the formation of the spores from the spore-mother-cells, often in great abundance. But all the mother-cells of a single sporangium are in nearly the same phase of rest or division as may be. Figs. I to 6 on the accompanying plate show several stages in the first division of these cells. Beside the completely resting nucleus of the cell shown in Fig. I, lie the very evident centrospheres. Here, where they have abundant room, they show the usual spherical form, but they sometimes appear smaller and flattened in resting cells, when confined in a narrow space, as in Fig. 7. Fig. Io shows the same thing from the root-tip of the Onion. In the stage shown in Fig. 3, the chromosomes have become individualized, and a remnant of the disappearing nucleolus, $n$, may still be seen. The centrosomes have just divided, apparently somewhat prematurely. In the two following stages the centrosomes are very plainly seen; but Fig. 6 fails to show them, probably because they are hidden by the daughter-nuclei. In the view of the young spore-tetrad (Fig. 7), which results from the second divisions in 
the mother-cell, one pair of centrospheres can be made out. Again, in the single isolated spore-cell of Osmunda cinnamomea (Fig. 9), these bodies are very distinct.

Farmer has lately published ('95) a detailed account of his studies of pollen-mother-cells of Lilium Martagon, which were briefly described in an earlier note ('93). He finds spindle-threads converging towards various irregularly placed granules in each spindle, and fails to recognize definite centrospheres. His published figures are largely reproduced from photographs of the objects, and he has had the goodness to send me several prints from the original negatives. It must be said that these figures do not arouse suspicions of poorly hardened or of abnormally developed material, in so far as they justify any judgment, to the same extent as did the woodcuts accompanying his preliminary note. But the results of photographing with high powers are utterly inadequate to the preservation of the finer details of a preparation. It is doubtful if any preparation of a plant-tissue has yet been made in which the centrospheres were sufficiently distinct to be sharply brought out in a photograph. Our chief dependence must still be on the camera lucida and the pencil. Those of Farmer's figures which are reproduced from drawings show none of the abnormal spindles which he describes. In view of the very remarkable agreement in the phenomena of nuclear division in the vascular plants in which it has been studied, one might almost feel justified in doubting the normal character of the phenomena described by Farmer for Lilium, because of their divergence from what occurs in Psilotum and Osmunda, as Farmer intimates I have done. But this would not be fair, especially when a proper basis for judgment is at hand. Unfortunately my own acquaintance with the cells studied by Farmer is very slight. This plant, however, has been a very favourite object for the study of karyokinesis with various other observers of the first rank. It is chiefly because of their difference in important respects from the observations of Strasburger, Guignard, and others, that I still venture to doubt that the phenomena described by Farmer are typical 
for the pollen-mother-cells of Lilium Martagon. The granules in and about Farmer's spindles appear to be of a nucleolar nature. And if Strasburger's present view that the rôle of the nucleolar substance is to form the spindle-fibres be correct, these apparently multipolar spindles may be unusual forms due to the presence of an excess of nucleolar substance in the cells concerned. At all events, as already suggested, a better knowledge of the relations of the amounts and proportions of the substances taken up by the plant, or of the influence of the conditions which further or retard growth, to the cell-constituents, may explain many such phenomena as those which are here in question.

For fixing material to show the centrosomes, not all fluids are equally good. With favourable objects alcohol does well. But in general, and especially for vegetative tissues, where the cell-structure is less conspicuously developed, nothing has given me better results than Hermann's platinum-chlorideosmic-acetic mixture. Subsequent staining by the long and tedious process recommended by this author for showing animal centrosomes, gives less satisfactory results than the simple fuchsin-iodine-green stain. As has been remarked, the former brings out various proteid granules in the cytoplasm as conspicuously as the centrosomes; with the latter stain the centrosomes come out distinctly and the other bodies remain uncoloured. The difference is shown in Figs. $1 \mathrm{I}$ and I2, from the root-tip of the Onion. Both are from material fixed with Hermann's fluid; but the section from which Fig. I I is taken was stained on the slide by Zimmermann's method, while Fig. 12 is from a root-tip stained in toto according to Hermann. The writer can therefore confirm the recent statements of Schaffner ('94), that centrospheres occur in their usual form in these young vegetative cells of the Onion root. But, as may be understood from Fig. I2, it is much easier to find bodies which one who is determined to find them may interpret as centrospheres, in sections stained by Hermann's method, largely used by Schaffner, than in those treated in a better way. 
That the centrospheres increase by division cannot be doubted. In the early stages of spindle-formation but a single one is found at each pole; and later, commonly just after the splitting of the chromosomes, in vascular plants, each is replaced by a pair. That the division takes place rapidly is shown by the fact that it is rare to find any stages in the process. But I have observed two cases in sporangia of Osmunda regalis which illustrate the mode of division. In Fig. 3 is a nucleus in an early stage of karyokinesis, whose centrospheres have arrived at the opposite poles and are beginning to divide, apparently earlier than usual. The astrosphere has become biscuit-shaped, and each centrosome has divided into two, which still remain very near together. In Fig. 8 is seen a later stage in the division of a tapetal nucleus and centrospheres, showing the constriction of each astrosphere into two about the separated centrosomes. It is, of course, impossible to assert that the increase of these organs always takes place in this way, since our knowledge of them is so fragmentary. But it is natural to ask why, if they can be formed de novo in the cell and are derivable from other cellconstituents, they should ever have acquired this power of division.

My objections to certain views which have been held concerning the relations of the centrosomes and the centrospheres ${ }^{1}$ to other cell-contents have since received important support. In the previous paper ('94) I tried to show the very fundamental structural and chemical differences between the centrospheres and the nucleoli, and that Karsten's belief ('94) in the derivation of the former from the latter at the beginning of karyokinesis in Psilotum was based on his having overlooked the centrospheres entirely, although they are not difficult, comparatively speaking, to demonstrate in that plant. Guignard ('94) has so fully confirmed this explanation that further arguments seem superfluous to demonstrate the essential

${ }^{1}$ As Guignard points out, not all writers on the subject have appreciated the important distinction between the two. 
improbability of a genetic connexion between the two sorts of bodies. It should quite satisfy any sceptic to examine such preparations as those from which Figs. I, 9, and Io are drawn with all possible exactness.

The behaviour of the centrospheres with reagents warrants a distinction between the denser slightly stainable centrosome, and the enveloping, highly refractive, and as yet unstained astrosphere. The substance of both appears to be, in general, protoplasmic; but the idea of its special character has been expressed in the terms archoplasm and kinoplasm, applied to it by Boveri and Strasburger, respectively. What we know of it seems to me to point to its specific nature. Whether the centrospheres are permanent organs of the cell it is impossible to say with certainty. So far as the astrosphere is concerned, Boveri ('95) denies this for animal cells, which afford much more satisfactory material than plants. It may well be that their substance contributes more or less to the formation of the spindle or is otherwise distributed in the cell. Such a fate would readily explain the difficulty of observing them in some stages of karyokinesis in Pellia. And the centrosomes, as has been said, would be quite unrecognizable without the characteristic envelope of the astrosphere. Yet in Pellia the centrospheres are most clearly seen when the radiations about them are most distinctly developed. This hardly supports the idea of the formation of the radiations from the substance of the astrosphere. On the other hand, the astrosphere appears, in the case of Psilotum, to be constant in all stages ; and my observations on Osmunda point to the same conclusion. It appears, then, that the centrospheres show no essential changes in their appearance, except when they are themselves undergoing division. If we omit the observations of Lauterborn ('93) on some Diatoms, and of Wager ('94) on a species of Agaricus, both of which seem to require confirmation, the structure and behaviour of the centrospheres in plants is strikingly uniform, so far as known. Judging from present knowledge, one may be warranted in believing it probable that these structures will prove to be 
permanent organs of the cell, increasing only by division. The question whether the centrosome or the whole centrosphere is permanent may be left to be answered by future researches. It is easy to conceive of the production of a surplus of these organs in abnormal cases by one or more extra divisions. As to whether the supernumerary ones are disposed of by subsequent fusions or by degeneration we have no evidence. Strasburger states ('95) that spindles from nuclei originally having three or four poles in Pellia finally always become bipolar, and is inclined to regard fusion as more probable than degeneration.

In all plant-cells in which it has been recognized, the centrosome is a tiny, homogeneous mass, so far as present methods of study show. Heidenhain has lately ('94) based on his observations upon leucocytes and giant-cells of marrow some new and radically different views of the centrosome from those above expressed. His discussion is long and very confusing to one whose acquaintance is chiefly with the definite and characteristic centrospheres of plant-cells. But Boveri ('95) has so clearly pointed out his misuse of terms and the entire agreement of the facts observed by him, when rightly understood, with the conception of this organ underlying the earlier work of van Beneden and Boveri, which is practically that above expressed, that no further discussion of his ideas is necessary. Heidenhain has shown, however, that in some leucocytes the centrosome may be so large as not to be uniformly stained, but to show deeplystaining granules within it. And in other animals similar structural features have been observed, as, for instance, in the centrosomes of the Sea-Urchin egg, by Boveri ('95).

The question of the cytoplasmic or nuclear origin of the centrosomes, which has been considerably debated and to which a good deal of importance has been attached, becomes more and more secondary as we realize the extent to which interchange between nucleus and cytoplasm occurs, and if we regard, with Boveri, the nuclear cavity as merely a space set apart for the chromosomes. This writer has done good 
service in pointing out that the question becomes interesting chiefly when asked from a phylogenetic point of view, though for a reply to it in this form we have as yet no materials whatever.

\section{PAPERS REFERRED TO.}

Boveri, Th., '95: Ueber das Verhalten der Centrosomen bei der Befruchtung des Seeigel-Eies, \&c. Verhandl. der phys.-med. Ges. zu Würzburg, Bd. XXIX, No. I, I 895 .

FARMER, J. BRETLAND, '93: On the nuclear division in the pollen-mother-cells of Lilium Martagon. Annals of Bot., Vol. vii, p. 393, I893.

'95: Ueber Kerntheilung in Lilium-Antheren, besonders in Bezug auf die Centrosomen-Frage. Flora, 1895 , Heft I, p. $5^{6}$.

AND ReEves, J., '94: On the occurrence of centrospheres in Pellia epiphylla, Nees. Annals of Bot., Vol. viii, p. 219, 1894.

Guignard, L., '91: Nouvelles Etudes sur la Fécondation, \&c. Ann. Sci. Nat., Bot., Sér. VII, T. XIV, p. I63, I89I.

'94 : Sur l'origine des sphères directrices. Journ. de Bot., T. VIII, p. $24 \mathrm{I}, \mathrm{I} 894$.

Heidenhain, M., '94 : Neue Untersuchungen über die Centralkörper und ihre Beziehungen zum Kern- und Zellen-protoplasma. Arch. für micr. Anat,, Bd. XLIII, p. 423, I894.

Humphrey, J. E., '94: Nucleolen und Centrosomen. Ber. der deutschen Bot. Ges., Bd. XII, p. I08, I894.

Karsten, G., '94: Ueber Beziehungen der Nucleolen zu den Centrosomen bei Psilotum triquetrum. Ber. der deutschen Bot. Ges., Bd. XI, p. 555, I894.

LAUterborn, R., '93 : Ueber Bau und Kerntheilung der Diatomeen. Verhandl. des naturh.-med. Vereins zu Heidelberg, Bd. V, p. II 2, I893.

RAwitz, B., '95: Centrosoma und Attractionssphäre in der ruhenden Zelle des Salamanderhodens. Arch. für micr. Anat., Bd. XLIV, p. 555, I895.

SCHAFFNeR, J. H., '94: The nature and distribution of attraction-spheres and centrosomes in vegetable cells. Bot. Gazette, Vol. xix, p. 445, I894.

Strasburger, E., '92 : Schwärmsporen, Gameten, pflanzliche Spermatozoiden, und das Wesen der Befruchtung. Histol. Beitr., Heft IV, p. 47, I892.

'95 : Karyokinetische Probleme. Jahrb. für wiss. Bot., Bd. XXVIII, p. I5 1,1895 .

WAGER, H., '94: On the presence of centrospheres in Fungi. Annals of Bot., Vol. viii, p. 321, I 894 .

Zimmermann, A., '93: Ueber das Verhalten der Nucleolen während der Karyokinese. Beitr. zur Morph. und Phys. der Pflanzenzelle, Bd. II, p. I, I 893 .

'94 : Referat über Humphrey, '94. Bot. Centralblatt, Bd. LIX, p. 57,1894 . 


\section{EXPLANATION OF FIGURES IN PLATE XX.}

Illustrating Dr. Humphrey's paper on some Constituents of the Cell.

All Figures are drawn from microtome-sections with the Abbé camera.

Figs. I-8. From sporangia of Osmunda regalis.

Fig. I. Spore-mother-cell in the resting stage, before separation. $\times 1000$.

Figs. 2-6. Successive stages in the first division of a definitive spore-mothercell. $\times$ I 200 .

Fig. 7. Three young spores of a tetrad formed from a mother-cell. $\times 1200$.

Fig. 8. Division of a tapetal cell, showing dividing centrospheres. $\times 1000$.

Fig. 9. Osmunda cinnamomea. Young spore, after separation of tetrad. $\times 1200$.

Figs. 10-1 2. From root-tip of Allium Cepa.

Fig. 10. Cell in resting stage. $\times \mathbf{I} 200$.

Fig. II. Cell with dividing nucleus, at time of splitting of chromosomes; fixed with Hermann's fluid, stained with fuchsin-iodine-green. $\times 1200$.

Fig. 12. Cell with dividing nucleus, at time of migration of daughter-chromosomes to poles; fixed and stained by Hermann's method for centrospheres, showing also many stained proteid granules. $\times$ I 200 . 


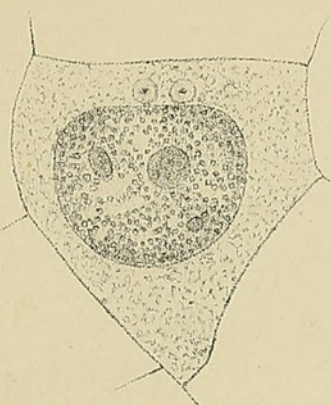

1.

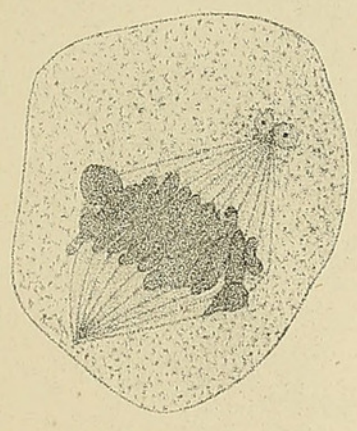

4.

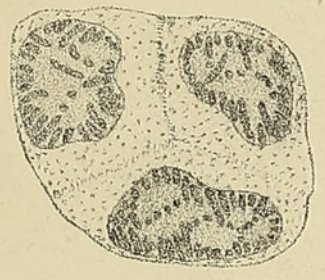

7.

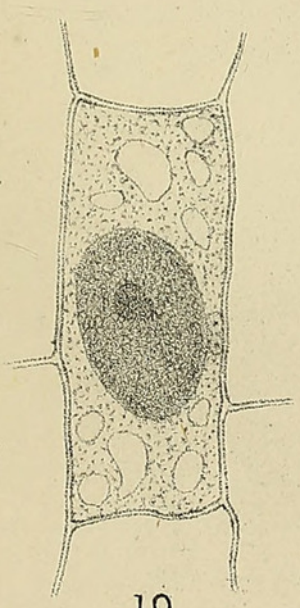

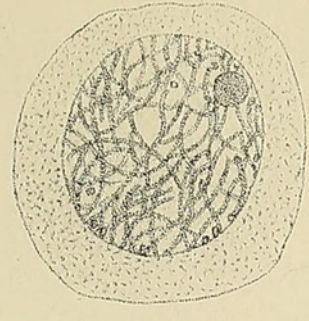

2.

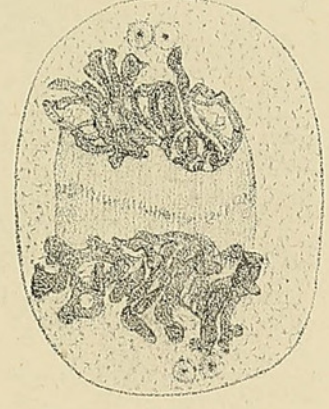

5.

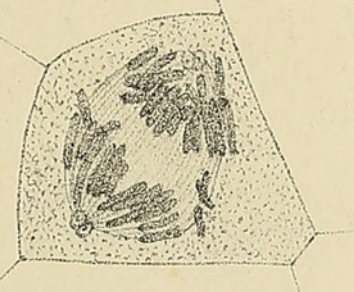

8.

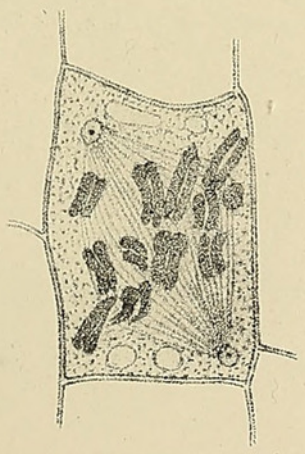

11.

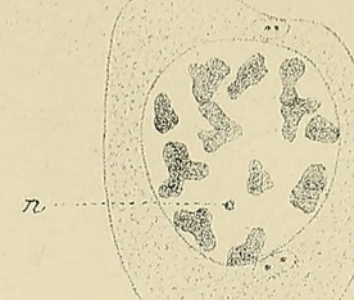

3.

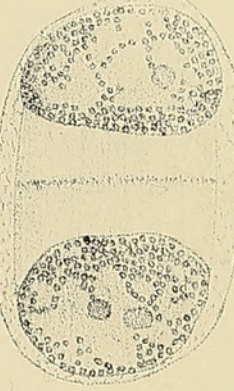

6.

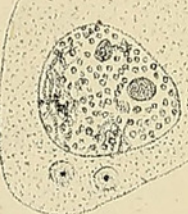

9.

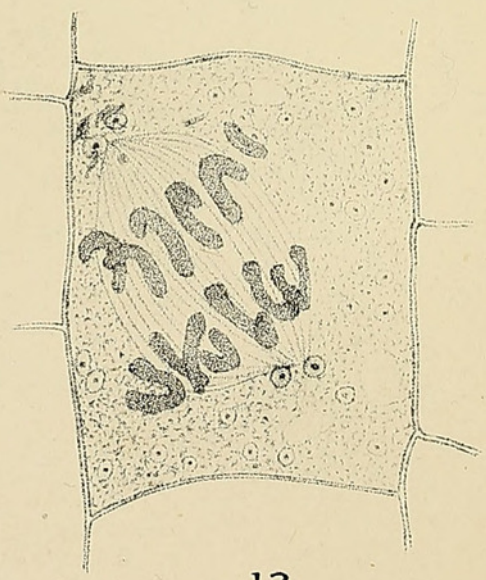

12. 


\section{$2 \mathrm{BHL}$ Biodiversity Heritage Library}

Humphrey, James Ellis. 1895. "On some constituents of the cell." Annals of botany 9, 561-579. https://doi.org/10.1093/oxfordjournals.aob.a090756.

View This Item Online: https://www.biodiversitylibrary.org/item/233478

DOI: https://doi.org/10.1093/oxfordjournals.aob.a090756

Permalink: https://www.biodiversitylibrary.org/partpdf/318395

\section{Holding Institution}

Smithsonian Libraries

\section{Sponsored by}

Biodiversity Heritage Library

\section{Copyright \& Reuse}

Copyright Status: Not in copyright. The BHL knows of no copyright restrictions on this item.

This document was created from content at the Biodiversity Heritage Library, the world's largest open access digital library for biodiversity literature and archives. Visit BHL at https://www.biodiversitylibrary.org. 